\title{
Soils, as the most important natural resources in Hungary (potentialities and constraints) - A review -
}

\author{
GY. VÁRALLYAY \\ Institute for Soil Sciences and Agricultural Chemistry, Centre for Agricultural \\ Research, Hungarian Academy of Sciences, Budapest
}

\section{Introduction}

Soils (soil-water-near surface atmosphere continuum, with its geology, relief and biota) represent the most important part of the natural resources of Hungary (StefanOVITS, 1963; National Atlas, 1989). Consequently, rational land use and proper soil management, aimed at guaranteeing normal soil functions, are important elements of the sustainable use of agro-ecosystems, and have special importance in the national economy, environment protection, and even in rural development (LÁNG et al., 1983; STEFANOvits, 1992). Society has utilized two unique and specific soil characteristics: multifunctionality (including fertility/productivity) and resilience (renewal ability) in different ways (rate, method, efficiency) throughout history, depending on the given natural conditions and socio-economic circumstances (GREENLAND \& SZABOLCS, 1990; VÁRALLYAY, 1998, 2015).

The basic aim of agriculture is the production of high-quality yields with low costs (inputs) and without undesirable environmental side-effects. Primary, secondary and tertiary agricultural production traditionally has great significance in the Hungarian national economy. The relative importance of its criteria (quantity, quality, efficiency, profitability, environmental impacts) has changed considerably during history, depending on the socio-economic conditions and sometimes according to forced political decisions (KREYBIG, 1956; CSETE \& VÁRALlYAY, 2004). Due to these challenges and irrational expectations - the character and sensitivity of the particular functions were not given proper consideration in many cases, and misguided management resulted in their over-exploitation, decreasing efficiency and, above a certain limit, in serious deterioration of the environment (VÁRALLYAY, 1989, 2006).

For rational and sustainable soil management, adequate information are required on soil forming factors and soil processes, on their interactions and on the possibilities (or limitations) of controlling them.

Correspondence to: GYÖRGY VÁRALLYAY, Institute for Soil Sciences and Agricultural Chemistry, Centre for Agricultural Research, Hungarian Academy of Sciences, H-1022 Budapest, 15 Herman Ottó út. Hungary. E-mail: g.varallyay@rissac.hu 
Soil science, soil survey and advisory practices in Hungary have constantly provided this information and successfully satisfied changing requirements (VÁrallyay, 2000b, 2003).

\section{Soils of Hungary}

Hungary (with a territory of $93000 \mathrm{~km}^{2}$ ) is situated in the deepest part of the hydro(geo)logically closed Carpathian Basin, where the soil-forming factors show high spatial and temporal variability. The majority of the land surface is covered by Quaternary (Pleistocene), Holocene and more recent geological deposits: loess, aeolian, alluvial and colluvial deposits with greatly varying stratification, texture, structure, hydromorphic character, minereal and chemical composition (STEFANOvits, 1963, 1992). The weather is influenced jointly and to varyig extents by the Atlantic, Continental and Mediterranean climates. The negative water balance $(500-550 \mathrm{~mm}$ average annual precipitation vs. a $800-900 \mathrm{~mm}$ potential evapotranspiration) of the Hungarian plains, is equilibrated by surface runoff, seepage and groundwater flow from the surrounding hilly regions to the lowland. The consequence is the accumulation of soluble materials (carbonates, Na-salts) originating from an extensive water catchment area (National Atlas, 1989; PÁLFAI, 2000).

The „original” parent material was translocated, redeposited and mixed many times, and soil formation was frequently interrupted by these processes and restarted under the modified new conditions, which later included the effect of various anthropogenic activities (STEFANOVITS, 1992).

Under the integrated influence of these soil-forming factors a highly variable, mosaic-like soil cover developed. Most soils are (relatively) young formations and sometimes change (relatively) rapidly even at the present time. The schematic soil map of Hungary is shown in Fig. 1 (STEFANOVITS, 1963).

The heterogeneous soil cover is well illustrated by various soil sequences (CSETE \& VÁRALLYAY, 2004; VÁRALLYAY, 2011a):

- chrono-sequence (according to the time that has elapsed from the beginning of uninterrupted soil formation): geological deposits $\rightarrow$ weakly developed soils (beginning of organic matter accumulation and structure formation) $\rightarrow$ developed soil types;

- topo-sequence (catena) (based on the influence of water and the appearance of hydromorphic symptoms): chernozem $\rightarrow$ meadow chernozem $\rightarrow$ meadow soil $\rightarrow$ peaty meadow soil $\rightarrow$ peat;

- leaching sequence (based on the intensity of the downward movement of water and soluble/suspendable materials): chernozem brown forest soil $\rightarrow$ Ramann brown forest soil $\rightarrow$ Brown forest soils with clay illuviation $\rightarrow$ pseudogley;

- salinity/alkalinity sequence (according to the quantity and profile distribution of soluble salts and ESP (Exchangeable Sodium Percentage): 
solonchak $\rightarrow$ solonetz $\rightarrow$ solonetzic meadow soils $\rightarrow$ salt accumulation in the deeper horizons;

- erosion sequence (according to the rate of erosion): non-eroded $\rightarrow$ slighly $\rightarrow$ moderately $\rightarrow$ strongly eroded.

The genetic soil types usually have different soil properties.

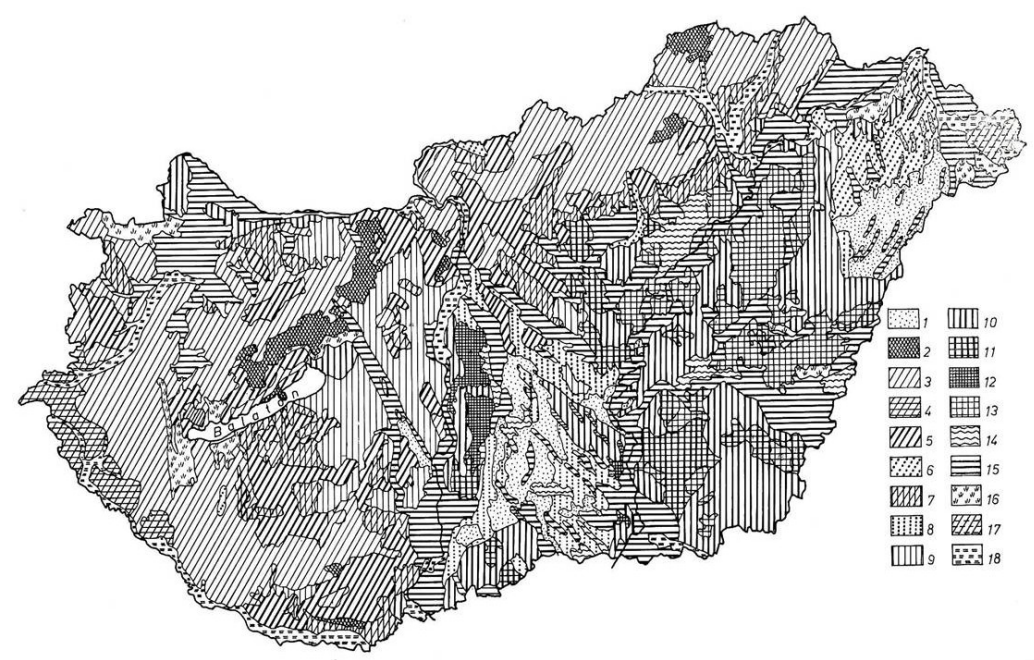

Fig. 1

Soil map of Hungary. 1. Blown sand. 2. Rendzinas. 3. Brown forest soils with clay illuviation. 4. Pseudogleys. 5. Brown earths (Ramann brown forest soils). 6. Sandy brown forest soils with thin interstratified layers of colloid and sesquioxide accumulation. 7. Chernozem brown forest soils. 8. Chernozem-type sandy soils. 9. Pseudomyceliar (calcareous) chernozems. 10. Lowland and meadow chernozems. 11. Meadow and lowland chernozems with salt accumulation in the deeper layers. 12. Solonchaks and solonchaksolonetzes. 13. Meadow solonetzes turning into steppe formation. 14. Solonetzic meadow soils. 15. Meadow soils. 16. Peats. 17. Soils of swampy forests. 18. Alluvial soils

During the more than 150-year history of agrogeology-pedology-agroecology a huge amount of soil information and data were collected and illustrated on maps with various scales (1:5000-1:5000000) and varying content for different purposes (SZABÓ et al., 1998; VÁrAllyaY, 2005; VÁRALlyAY et al., 1980, 1994, 2010; National Atlas, 1989). In recent decades a comprehensive survey-analysesmapping-monitroing system was developed, organized into an up-to-date soil database and this has been efficiently used for various practical purposes, especially for rational and sustainable soil and water management and environment protection (LÁNG et al., 1983; VÁRALLYAY et al., 1980, 1985).

The accumulated information provethat the natural conditions of the Carpathian Basin (particularly the lowlands and plains) are generally favourable for rainfed biomass production (LÁNG et al., 1983; CSETE \& VÁRALLYAY, 2004; VÁRALLYAY, 2015). These conditions, however, show substantial spatial and temporal variability, 
the irregularity of which makes them hard to predict, are often extreme and react sensitively react to various natural or human-induced stress. The favourable agroecological potential is limited by soil degradation processes, extreme moisture regime (simultaneous hazard of flood, waterlogging, over-moistening and drought sensitivity) and unfavourable changes in the biogeochemical cycles of elements, especially of plant nutrients and environmental pollutants.

\section{Limiting factors of soil multifunctionality andsoil degradation processes}

The main factors limiting soil multifunctionality, including soil fertility and productivity are shown in Fig. 2 (SZABOlCS \& VÁrallyay, 1978; VÁRALlyaY, 2006).

Sustainable land use and soil management may react to these limitations in two different ways (LÁNG et al., 1983):

- adaptation to the given conditions by rational „site-specific" land use, proper cropping pattern and adequate precision agrotechnology;

- modifications (improvements) in the unfavourable conditions by soil reclamation and amelioration, including the development of proper infrastructure, water management and soil conservation practices.

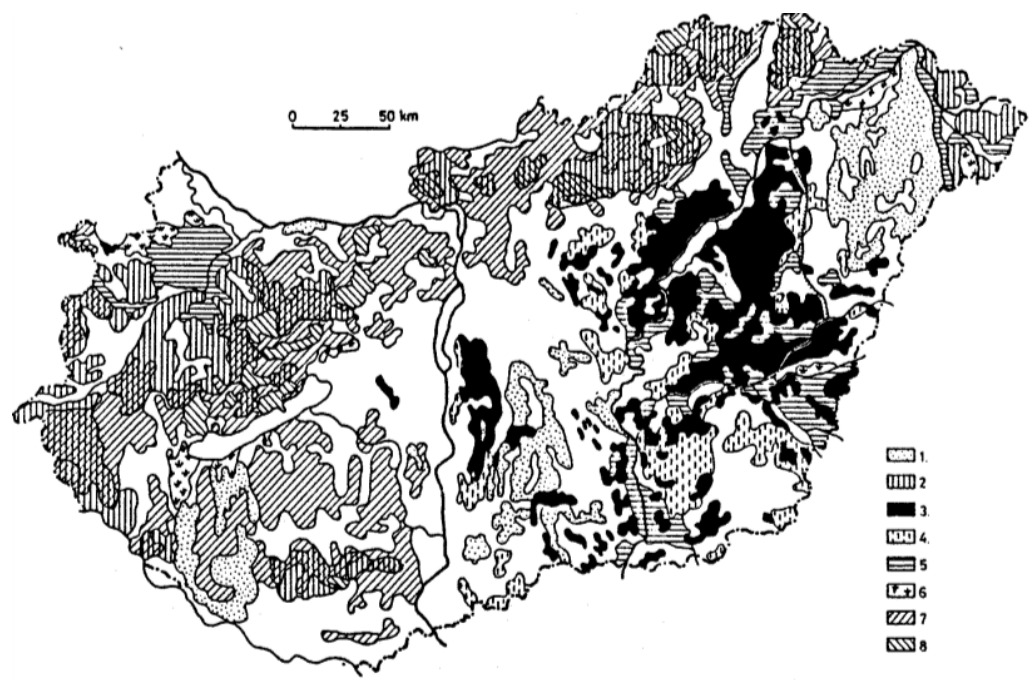

Fig. 2

Map of the factors limiting soil fertility in Hungary. 1. Extremely coarse texture $(8 \%$ of the total area of Hungary); 2. Acidity (12.8\%); 3. Salinity and/or alkalinity (8.1\%);

4. Salinity and/or alkalinity in the deeper layers (2.6\%); 5. Extremely heavy texture (6.8\%); 6. Waterlogging or peat formation $(1.7 \%)$; 7. Erosion (15.6\%); 8. Shallow depth $(2.3 \%)$ 
The necessity and rationality of the amelioration of soils with limited fertility depends on economical (cost-benefit) analysis and ecological considerations. The radical amelioration of salt-affected soils, sandy soils or peatlands requires expensive complex measures, therefore it is not economic. At the same time the saline lakes and soils, wetlands and sand regions are in many cases protected ecosystems, being the habitats of protected plants and animals, thus having special environmental value. These areas must be kept in (or restored to) their „original” condition, which will require special measures (LÁNG et al., 1983; CSETE \& VÁRALLYAY, 2004; NÉMETH et al., 2005; BIRKÁs, 2008).

Soil degradation is usually a complex process involving several features that contribute to unfavourable changes in soil processes and soil properties, the loss of or decrease in soil fertility and productive capacity; limitations in normal soil functions and/or serious environmental deterioration. Soil degradation may be the result of natural factors and/or human activities.

In the Carpathian Basin the most important soil degradation processes are as follows (VÁRALLYAY, 1989, 2006):

1. Soil erosion by water or wind (STEFANOVITS, 1992).

2. Soil acidification (VÁrAlLYAY et al., 1993).

3. Salinization/alkalization/sodification (SZABOLCS, 1965; VÁRALLYAY, 1968; SzABOLCS et al., 1969).

4. Physical soil degradation, such as structure destruction, compaction, surface sealing, etc. (VÁRALLYAY \& LESZTÁK, 1990; BIRKÁs, 2008).

5. Extreme moisture regime: simultaneous hazard of over-moistening, waterlogging and drought-sensitivity (PÁLFAI, 2000; VÁRALLYAY, 2006, 2011a).

6. Biological degradation, such as unfavourable changes in soil biota or a decrease in soil organic matter.

7. Unfavourable changes in the biogeochemical cycles of elements, especially in the regime of plant nutrients, such as leaching; volatilization, or biotic and abiotic immobilization (LÁNG et al., 1983; VÁRALlyay, 1985; CSETE \& VÁRALlyay, 2004).

8. Decrease in the buffering capacity of soil, soil pollution, and environmental toxicity (VÁRAllyay, 1996; ADRIANO et al., 2003; LÁNG et al., 2004; VÁRALLYAY et al., 2010).

In spite of the already large and increasing area of degraded lands on all continents, it can be stated that soil degradation is not an unavoidable consequence of intensive (but rational!) agricultural production and social development! Most soils are resilient to a certain extent, consequently, most of the soil degradation processes and their consequences can be efficiently prevented, eliminated or at least moderated. This, however, necessitates permanent control measures and the widespread adption of soil (and water) conservation technologies, which are the indispensable elements of sustainable (agricultural) development and up-to-date site-specific precision soil management (NÉMETH et al., 2005; VÁRALLYAY, 2014). 
For the efficient control of soil degradation processes exact information are required on

- the reasons (causative fafctors) of the particular degradation;

- the susceptibility/sensitivity/vulnerability of the soil to various environmental (natural and human-induced) threats;

- possibilities of preventive measures and their potential impacts (SZABÓ et al., 1998; VÁRALLYAY, 1989, 2000a).

In recent years the revolutionary development in in situ and laboratory analytics, remote sensing, informatics, computer technology, GIS/GPS applications, etc. have given opportunities for up-to-date database development, including a comprehensive assessment of soil susceptibility/sensitivity/vulnerability to various types of natural or human-induced stresses (SZABÓ et al., 1998; VÁRALLYAY, 1994, 2000a). Hungary has actively participated in such international programmes as GLASOD, SOTER, SOVEUR, PHARE-MERA and the EU Strategy of Soil Protection (VÁrallyay et al., 1994; NÉMETH et al., 2005; Soil Atlas of Europe, 2005; VÁRALLYAY, 2005).

Soil degradation regions were identified and maps were prepared on the susceptibility of soils to

- water and wind erosion (STEFANOVITS, 1992);

- acidification (VÁRALLYAY et al., 1993) (Fig. 3);

- salinization/sodification (SZABOLCS, 1965; SZABOLCS et al., 1969);

- physical degradation (structure destruction, compaction) (VÁRALlYAY \& LESZTÁK, 1990) (Fig. 4);

- nutrient load and chemical pollution (VÁrALlYAY, 1996; LÁNG et al., 2004).

Two examples are shown in Figures 3 and 4.

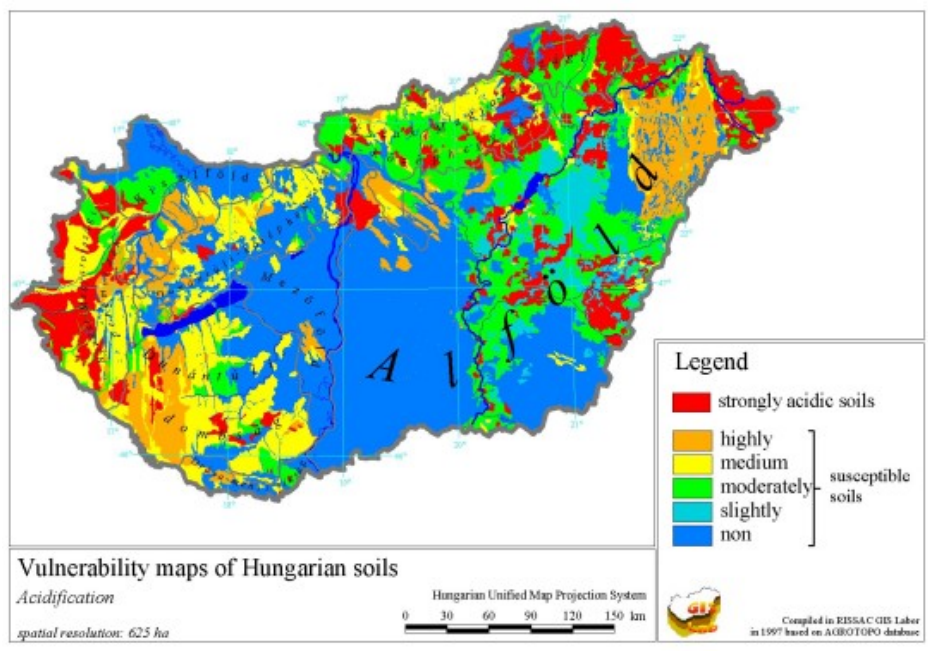

Fig. 3

Susceptibility of soils to acidification 


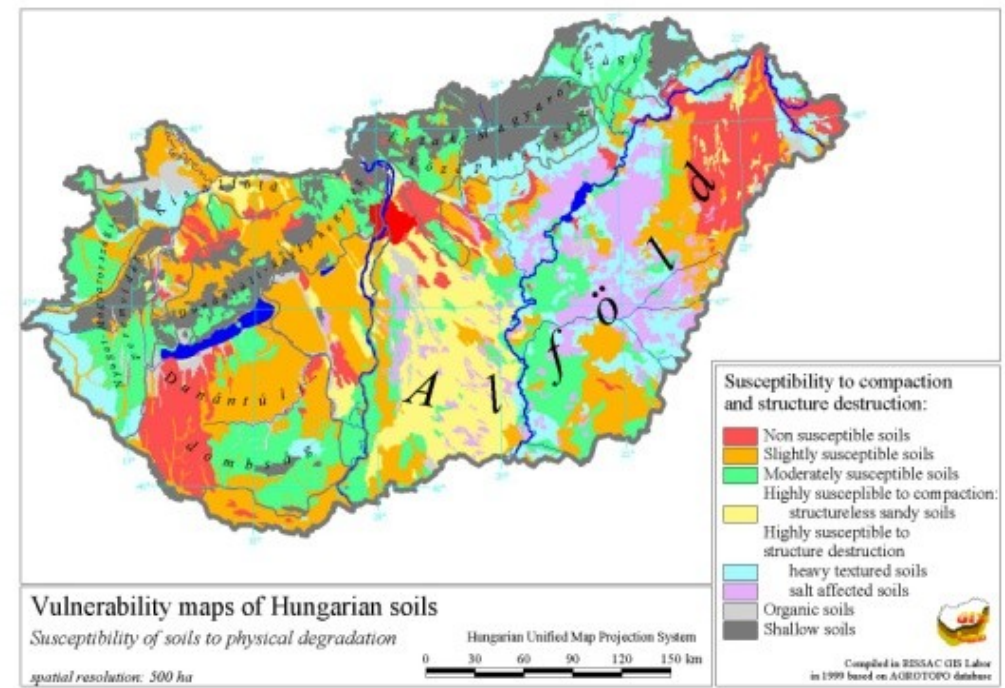

Fig. 4

Susceptibility of soils to physical degradation

\section{Extreme soil moisture regime}

In future water will be the determining (but hopefully not limiting) factor of food security and environmental safety in the Carpathian Basin, especially in its deepest part: in the Hungarian Plain. Consequently, improvement of water use efficiency will be the key issue of agricultural production, rural development and environment protection and the control of soil moisture regime will be an imperative task without any other alternatives (PÁLFAI, 2000; SOMLYÓDY, 2000; VÁRALLYAY, 2006, 2010, 2011a).

Water resources are limited in the Pannonian Plains. The average annual atmospheric precipitation exhibits extremely high territorial and temporal variability, even on micro-scale (Fig. 5).

The frequency of intense rainfall (,rain bombs”: > 50-60 mm/2 hours, thunderstorms, sometime hails) have increased considerably and is forecasted will increase in the future. The changing rain: snow ratio and rapid snow melt is also predicted.

Under such conditions a considerable part of the precipitation is lost due to surface runoff ( $\rightarrow$ increasing flood hazard), downward filtration and evaporation from the deep and open cracks of heavy-textured swelling-shrinking vertisols ( $\rightarrow$ increasing drought sensitivity). The water balance in the Carpathian Basin is negative: $500-600 \mathrm{~mm}$ precipitation vs. $700-750 \mathrm{~mm}$ potential evapotranspiration. 


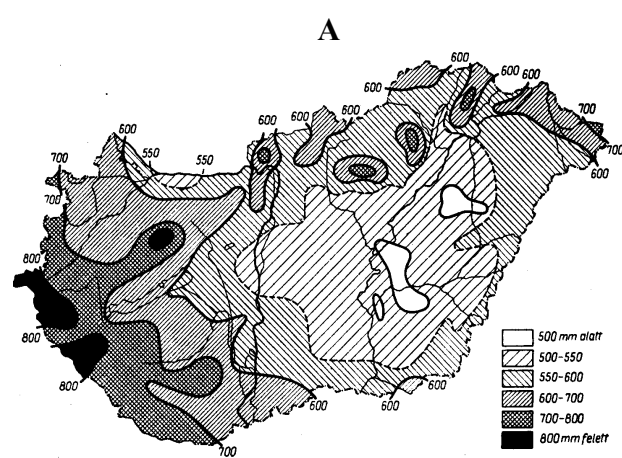

C

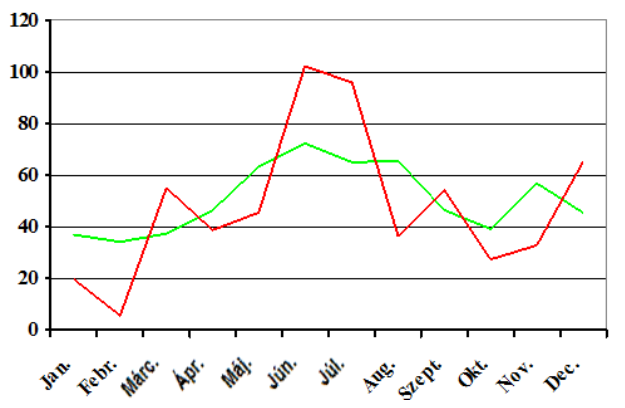

B

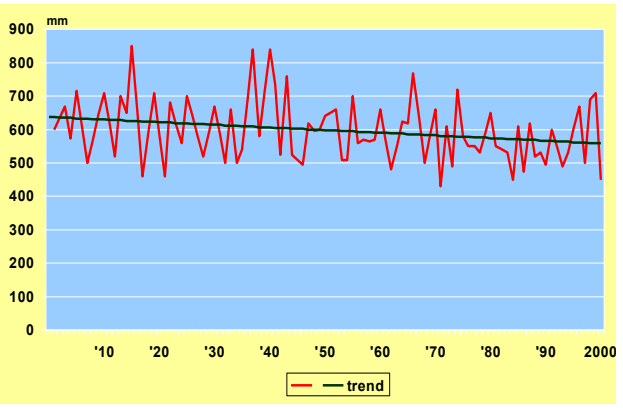

D

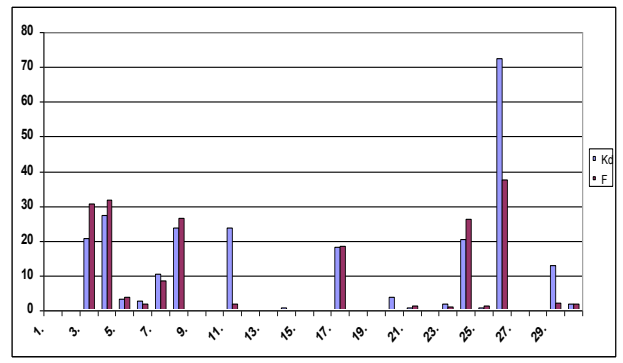

Fig. 5

Territorial and time distribution of atmospheric precipitation in Hungary.

A. Geographical distribution of average annual precipitation over the last 100 years.

B. Average annual precipitation in Hungary in the $20^{\text {th }}$ century. C. Monthly distribution of the annual precipitation: long-term average (grey line) and in 2008 (black line). D. Daily distribution of monthly precipitation (May 2008) at two adjacent meteorological stations

It is equilibrated by horizontal inflow (surface runoff; seepage in the unsaturated zone; groundwater flow) from the surrounding hilly areas, which leads to the accumulation of weathering products of a large water catchment area in a relatively small accumulation territory ( $\rightarrow$ high rate of salt affected soils): Fig. 6 (VÁRALlYAY, 1968).

Due to the predicted higher temperatures and aridity, there - will no increase in precipitation in the future, and its spatial and time distribution will be unfavourable and sometimes extreme as a result of the situation and two additional facts:

- the heterogeneous microrelief of the "flat" lowland;

- the highly variable, sometimes mosaic-like soil cover and the unfavourable physical and hydrophysical properties of some soils (mainly due to heavy texture, high clay and swelling cly content, or high sodium saturation: ESP 


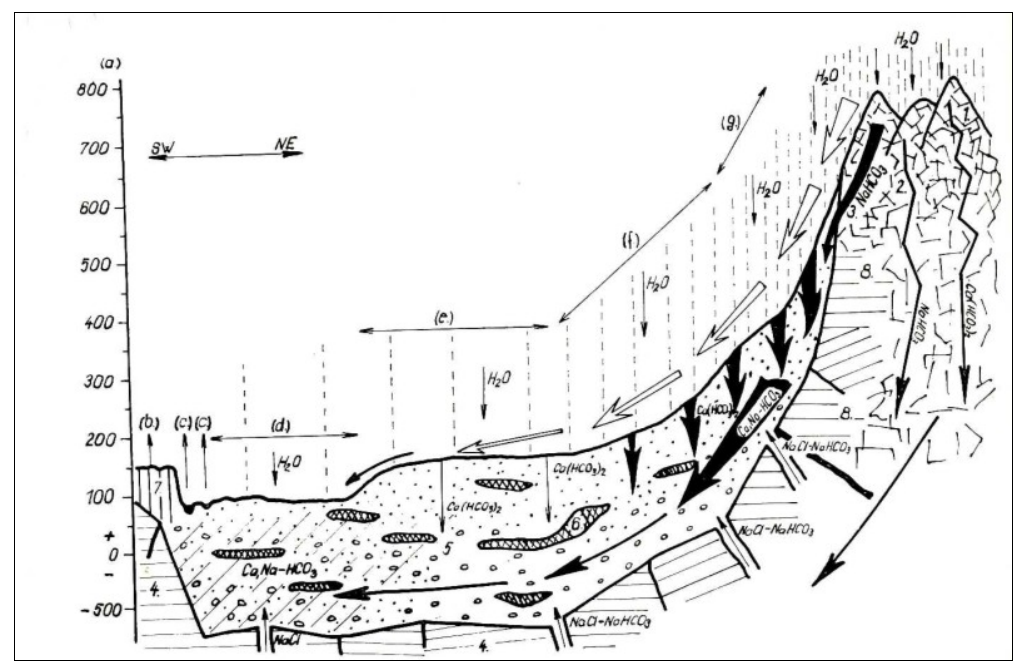

Fig. 6

The process of salt accumulation in the Hungarian Danube Valley. Legend: a) Height above sea level, m; b) Trans-Danubian loess plateau; c) Danube; d) Danube Valley; e) Sand-ridge between the Danube and the Tisza; f) Basin periphery; g) Hungarian central range of mountains. 1. Limestone; 2. Rhyolite, andesite; 3. Rhyolite and andesite tuff;

4. Impermeable Pannon clay; 5. Fluviatile gravel, sand, sandy silt; 6. Clay lens; 7. Loess; 8. Pleistocene clay

There will be an increased risk (frequency, duration, „seriousness”) of extreme hydrological events (flood, waterlogging, over-moistening vs. drought) and extreme soil moisture regimes, and the unfavourable/harmful/catastrophic economic, ecological, environmental (erosion-sedimentation, salinization/sodifi-cation, landscape destruction) and other (damageto infrastructure) consequences will also increase (PÁlfai, 2000; VÁRALlyay, 2011a).

The average quantity of incoming surface waters (rivers) is about 110-115 $\mathrm{km}^{3} /$ year in Hungary and this is unlikely to increase, particularly in critical lowwater periods, for two reasons (SZABOLCS, 1965):

- the lower quantity and greater spatial and temporal variability of atmospheric precipitation, increasing the risk of high-intensity rainfall, changes in the rain: snow ratio and snow-melt behaviour, land use changes and surface runoff characteristics in the Upper Danube Basin areas;

- the fact that a certain quantity and quality of transboundary surface waters must be guaranteed for the Lower Danube Basin countries (at present this outflow is about $\left.115-120 \mathrm{~km}^{3}\right)$.

A considerable part of subsurface waters (especially in the poorly drained East Hungarian Plain) has poor quality (high salt content, unfavourable ion composition), with the threat of harmful salinization/sodification processes. In the Danube-Tisza Interfluve sand plateau, consecutive dry years and the overexploitation of subsurface waters have resulted in a sinking of the groundwater table, 
the consequences being increasing aridity and even "desertification symptoms". Only in small areas is good quality groundwater able to contribute efficiently to supplying water for plants (PÁLFAI, 2000; VÁRALLYAY, 2011a).

A 5-step model was elaborated to calculate the quantity of water and solutes capillarily transported from the fluctuating groundwater to the overlying soil horizons, and this was successfully applied to determine the optimum depth (optimum regime) of good quality groundwater (contributing to satisfying the water requirements of plants) and the critical depth (critical regime) of poor quality groundwater (preventing the secondary salinization/ sodification of soil) (VÁRALlYAY \& RAJKAI, 1989).

Under such conditions the fact that

soil has the largest potential natural water storage capacity

is of vital importance, and this has been precisely proved by the comprehensive soil physical/hydrophysical database and monitoring system set up in Hungary (VÁRAllyAY, 2010, 2011b; VÁRAllyaY et al., 1980). The system distinguishes 9 main categories based on textural class; total porosity as maximum water storage capacity $\left(\mathrm{WC}_{\mathrm{t}}\right)$, field capacity $(\mathrm{FC})$, water retention (WR), wilting percentage (WP), and available moisture range (AMR); infiltration rate (IR), permeability (P) and saturated hydraulic conductivity $(\mathrm{K})$. The subcategories were classified on the basis of horizon sequence and the main reason for their limited FC, WR or IR. A schematic map of the distinguished categories is given in Fig. 7. On the basis of the database the main characteristics can be quantitatively interpreted for soil layers, soil profiles; physico-geographical, administrative, farming or mapping units (e.g. ecological region, water catchment area, county, settlement, farm, agricultural field, etc.) (VÁRAllyay, 2010; VÁRALlyaY et al., 1980). The database serves as a basis both for evaluating the waterlogging or over-moistening hazard and drought sensitivity of a certain area and for rational regional or local water management activities.

In ideal cases (potentially) $30-35 \mathrm{~km}^{3}$ water can be stored in the pore volume of the $0-100 \mathrm{~cm}$ soil layer, which is more than half of the $500-600 \mathrm{~mm}$ average annual atmospheric precipitation. About $50 \%$ of this quantity is "available moisture content", which may satisfy the water requirements of the natural vegetation and cultivated crops even in the case of high biomass production and yield levels (VÁRALlYAY, 2011b). This favourable situation is, however, countered by the increasingly high risk, hazard, frequency and duration of extreme hydrological events, sometimes occuring in the same place in the same year. These are characteric features of the Pannonian Plains and can be attributed to the high territorial and temporal variability of atmospheric precipitation, to the rain: snow ratio and snowmelt characteristics, to the relief (including microrelief) and to the soil conditions; vegetation and land use practices. Their main consequences are losses of water (evaporation, surface runoff, seepage, deep filtration), soil (organic matter and nutrients), biota, vegetation, yield and energy (VÁRALLYAY, 2006). 


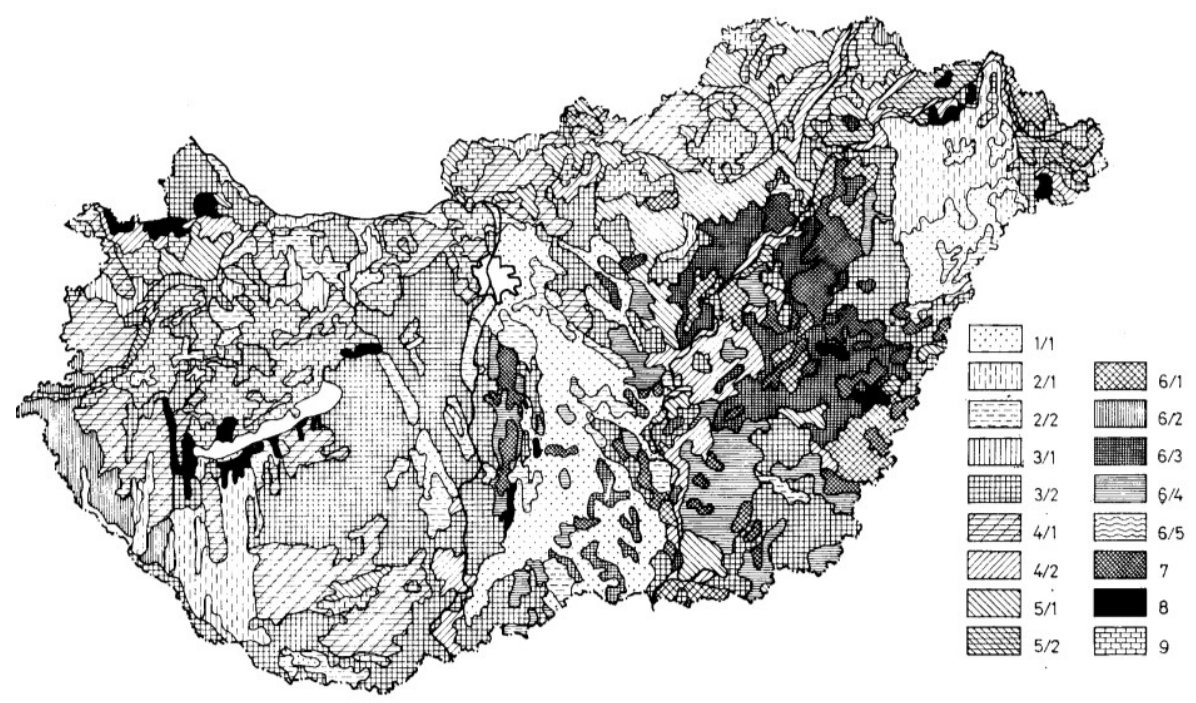

Fig. 7.

Hydrophysical characteristics of soils in Hungary. 1. Soils with very high IR, P and K; low FC; very poor WR (10.5\% of the total $93035 \mathrm{~km}^{2}$ area of Hungary); 2 . Soils with high IR, P and K; medium PC; and poor WR (11.1\%); 3. Soils with good IR, P and K; good FC; and good WR (24.9\%); 4. Soils with moderate IR, P and K; high FC; and good WR (19.1\%);

5. Soils with moderate IR, poor P and K; high PC and high WR (6.2\%); 6. Soils with unfavourable water management: very low IR and K (14.8\%); 7. Soils with extremely unfavourable water management due to high salinity/sodicity: extremely low AMR, IR and K (3.6\%); 8. Soils with good IR, P and K; and very high FC (organic soils) (1.3\%); 9. Soils with extreme moisture regime due to shallow depth $(8.5 \%)$.

The main profile variants: (1) texture becomes lighter with depth (soils formed on relatively light-textured parent material): $2 / 1,3 / 1$; (2) uniform texture within the profile: $1 / 1,2 / 2,3 / 2$, $4 / 2,5 / 2$; (3) relative clay accumulation in the horizon B: $4 / 1,5 / 1$. Profile variants of category 6: 6/1: highly compacted, heavy-textured soils with poor structure; $6 / 2$ : pseudogleys; $6 / 3$. deep meadow solonetzes and solonetzic meadow soils; $6 / 4$ : soils with salinity/sodicity in the deeper horizons; 6/5: peaty meadow soils.

What is the main reason for this contradiction between the huge water storage capacity and the extreme moisture situation?

Only (?) $31 \%$ of Hungarian soils represent an "ideal case" for the efficient use of the potential water storage capacity, having "favourable" hydrophysical properties, but $43 \%$ of the soils have unfavourable and $26 \%$ moderately favourable water management characteristics, due to various limiting factors, as it can be seen in Fig. 8 (VÁrallyay, 2010, 2011b). 


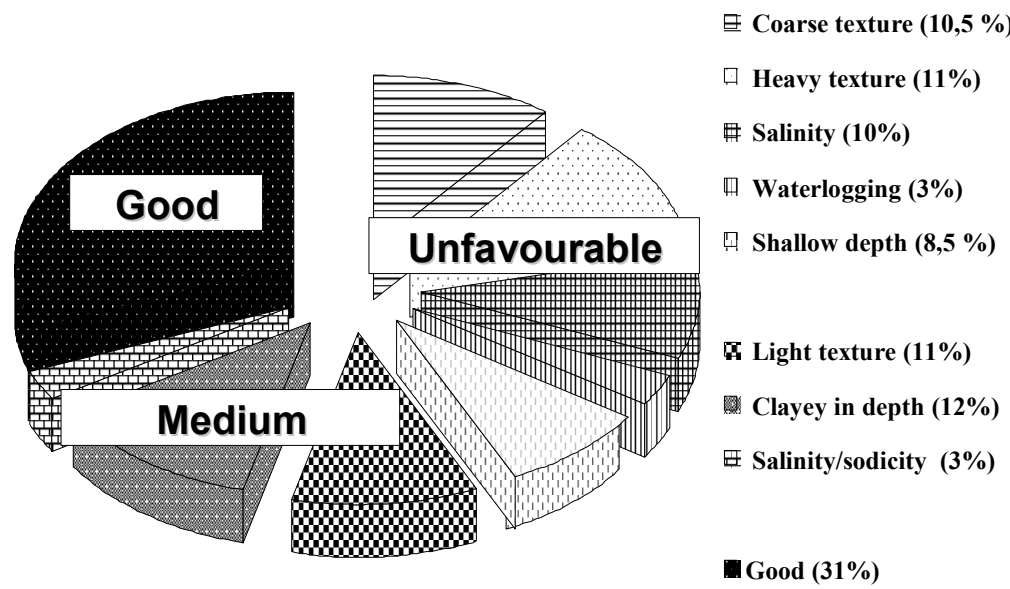

Fig. 8

Moisture regimes in Hungary and the reasons for them

The huge natural water storage capacity of a considerable part of soils is not exploited because of the following limiting factors (VÁRALLYAY, 2010; VÁRALLYAY, 2011b):

- The pore space is not "empty": it is filled up by a previous source of water (rain, melted snow, capillary transport from groundwater, irrigation etc.): "filled bottle effect";

- The infiltration of water (rain, melted snow) into the soil is prevented by the frozen topsoil: "frozen bottle effect";

- The infiltration is prevented or reduced by a nearly impermeable soil layer on, or near to the soil surface (solid rock; cemented soil horizons; ,plough pan", etc.): "closed bottle effect";

- The water retention of the soil is poor and the infiltrated water is not stored in the soil, but percolates through the soil profile (light-textured sandy soils): "leaking bottle effect";

- The stored water and soluble compounds are not available for plants and the biota, as they are strongly bounded by soil particles (heavy soils): ,dead water".

These limitations outline the main tasks involved in soil moisture control:

- to help the infiltration of water into the soil;

- to promote the useful storage of infiltrated water within the soil without any unfavourable environmental consequences;

- to reduce the immobile (strongly bound "dead") fraction of the stored water;

- to reduce the loss of atmospheric precipitation and irrigation water via evaporation, surface runoff and deep filtration; 
- to drain the harmful surplus amount of water from the soil profile and from the area, thus improving vertical and horizontal drainage conditions (prevention of over-saturation and/or water-logging).

There are many ways which the basic objectives can be put into practice (NÉMETH et al., 2005; BIRKÁs, 2008; VÁRAllyay, 2010). Scientific and technical developments are offering more and more new tools, techniques and technologies for such activities. Our task is to select and implement suitable, efficient sitespecific alternatives. Most of these „moisture management actions” are, at the same time, efficient environment control measures and reduce the risk and unfavourable consequences of other stresses (soil degradation processes, nutrient stress, pollution hazard, etc.).

\section{Control of soil processes}

The multifunctionality, fertility/productivity and resilience of soil - this important, conditionally renewable natural resource - are determined by the integrated influences of soil properties, which are the results of soil processes, by mass and energy regimes, abiotic and biotic transport and transformation, and by their interactions under the combined influences of soil-forming factors. Any direct or indirect, positive or negative, natural or anthropogenic soil-related intervention and activity will influence the land through these processes. Consequently, the control of soil processes is a great challenge to and the main task of soil science and soil management.

The efficient control of soil processes necessitates the following consecutive steps (VÁRALLYAY, 2000):

- the registration of facts and consequences (information on land and soil characteristics, land use, cropping patterns, applied agrotechnics and yields, with their spatial and temporal variability);

- the evaluation of potential causes (definition and quantification of soil processes, analysis of influencing factors and their mechanisms);

- the assessment of theoretical, real, rational and economic possibilities for the control of soil processes (including their risk assessment and impact analysis);

- the elaboration of efficient technologies for the „best” control alternatives (best management practice).

The control of soil processes can be the scientific basis for the planning and implementation of sustainable land use and rational soil management to ensure desirable soil multifunctionality without any undesirable environmental sideeffects. Such control requires adequate soil information:

- exact, reliable, "detectable" (preferably measurable) and accurate, quantitative territorial data on well-defined soil and land properties, including the characterization of their spatial (vertical, horizontal) and temporal variability and pedotransfer functions; 
- on elementary and integrated soil processes and biogeochemical cycles, including their determining and influencing factors and their mechanisms, and

- on the actual and/or potential impacts of various direct and indirect human activities.

This information will make it possible to perform comprehensive

- sensitivity analysis, evaluating the susceptibility/vulnerability of soils to various types of natural and human-induced, positive or negative stress;

- impact analysis, evaluating the positive or negative impacts of various human activities;

- risk analysis, evaluating the potential hazard of various unfavourable processes, and characterizing and quantifying their probability, frequency, duration and intensity.

During the last 100 years a large amount of such soil information became available in Hungary as a result of long-term observations, soil surveys and analytical, mapping and monitoring activities conducted at global (1:5000000), continental (1:1000000), national (1:500000-1:200000), regional (1:1000001:50000), farm (1:25000-1:10000) or field (1:10000-1:5000) scale. This has been used successfully in various national and international programmes, projects, advisory services and practical soil-related activities, including the World Soil Map, Soil Atlas of Europe, SOTER, GLASOD, SOVEUR, the assessment of agroecological potential and environmental susceptibility, various climate change and water management programmes, land evaluation, pedotransfer functions, AIIR, MARTHA, TIM etc. A considerable part of the data has been organized into GIS databases, giving the opportunity for the efficient control of soil processes and soil functions (SZABÓ et al., 1998; Soil Atlas of Europe, 2005; VÁRALLYAY, 2000b, 2005; VÁRAllyaY et al., 1980, 1985, 1994, 2010; MAKÓ et al., 2010; CsORBA et al., 2014; Kocsis et al., 2014).

\section{Conclusion}

Soil is a four-phase, four-dimensional, polydisperse medium with three unique characteristics: conditionally renewability, natural resource, resilience and multifuncionality. In addition to its primary function, which is to produce multipurpose biomass (food, fodder, industrial raw material, alternative energy), modern society is making increasingly intensive use its other environmental (buffering, detoxication, biodiversity), technical (place and material for construction, wellness) and even cultural (restoration of the natural and human heritage) functions. The overuse or irrational use of land may lead to the deterioration of soil multifunctionality and to acute cases may cause natural catastrophes with their tragical economical, ecological, environmental and social consequences.

The control of soil processes requires continuous actions based on a comprehensive database, risk assessment, impact analysis and exact prognosis. 
Efficient control is an important element in rational, economically viable, environmentally sound and socially acceptable sustainable development, providing a sound bases for a better life, with a sufficient quantity of healthy, good quality food, clean water and a pleasant environment (CSETE \& VÁRALLYAY, 2004; VÁRALLYAY, 2000, 2014).

\section{Summary}

Soils (the geological strata-soil-water-near surface atmosphere-biota continuum) are the most important conditionally renewable natural resources in Hungary. Society uses, and sometimes misuses, soil resources by utilizing three specific and unique soil characteristics: multifunctionality, fertility and resilience. The rational and sustainable use, protection and conservation of soil resources, aimed at maintaining their desirable multifunctionality, are priority tasks for biomass production, environment protection and rural development and also for sustainable development.

As a result of great variety of soil-forming factors and soil formation/degradation processes, the soil cover of the Carpathian Basin is rather heterogeneous, and in some places mosaic. The natural conditions (particularly in the lowlands and plains) are generally favourable for multipurpose (food, fodder, industrial raw material, alternative energy source) rainfed biomass production. These conditions, however, exhibit very great spatial and temporal variability, which is irregular and consequently hardly predictable, often involving extremes and sensitive responses to various types of natural or human-induced stresses. The main constraints are:

1. Soil degradation processes: soil erosion by water and/or wind, acidification, salinization/sodification, structure destruction and compaction, biological degradation.

2. Extreme moisture regime: simultaneous hazard of flood, waterlogging, over-moistening and drought sensitivity.

3. Unfavourable changes in the biogeochemical cycles of elements, especially of plant nutrients and environmental pollutants (organic matter decline; leaching-accumulation; fixation-release; (im)mobilization).

Water resources are rather limited in the Carpathian Basin (especially on the Hungarian Plains, which are the deepest part) and show high (and still increasing) spatial and temporal variability. The risk, frequency, duration and seriousness of extreme meterological/hydrological situations and are expected to increase. Water is already and will continue to be an important (and sometimes determining) factor for soil processes and soil functions. Making it a key element in sustainable development. Consequently, the efficient use of the water reservoir function of the soil and the improvement of water use efficiency are of particular importance. These simultaneously decrease surface runoff, deep filtration and evaporation water losses, and reduce the risk of extreme hydrological situations (flood, waterlogging, over-moistening vs. droughts) and their undesirable/harmful (sometimes catastrophic) economical, ecological, environmental and social consequences. 
The control of soil processes is a great challenge to and the main task of modern soil science aimed at rational and sustainable soil management.

Keywords: soil multifunctionality, environmental vulnerability, soil degradation, soil moisture regime, control of soil processes

\section{References}

AdRIANO, D. C., NÉMETH, T. \& GYŐRI, Z. (Eds.), 2003. Natural Attenuation of Metals Along the Tisza River-Floodplain-Wetlands Continuum. University of Georgia, RISSAC, University of Debrecen.

BirKÁs, M., 2008. Environmentally-sound Adaptable Tillage. Akadémiai Kiadó. Budapest.

Csete, L. \& VÁrallyay, Gy., 2004. Agroecology, environmental relations of agroecosystems and possibilities of their control (In Hungarian). Agro-21 Füzetek. 27. 217.

Csorba, Sz., Berényi Üveges, J. \& Makó, A., 2014. Relationship between soil properties and potentially toxic elements based on the dataset of the Soil Information and Monitoring System in Hungary. Central European Geology. 57. (3) 253-263.

Greenland, D. J. \& Szabolcs, I. (Eds.), 1990. Soil Resilience and Sustainable Land Use. CAB International. Wallingford.

KreYBIG, L., 1956. Factors and Concepts of Agrotechnics (In Hungarian). Akadémiai Kiadó. Budapest.

Kocsis, M., Tóth, G., Berényi Üveges, J. \& MaKó, A., 2014. Presentation of soil data from The National Pedological and Crop Production Database (NPCPD) and investigations on spatial representativeness (In Hungarian). Agrokémia és Talajtan. 63. 223-248

LÁNG, I., CSETE, L. \& HARNos, Zs., 1983. Agro-ecological potential of Hungarian agriculture (In Hungarian). Mezögazdasági Kiadó. Budapest.

LÁNG, I., JolánKaI, M. \& KöMíves, T., 2004. Pollution Processes in Agri-environment. Akaprint. Budapest.

Makó, A., Tóth, B., Hernádi, H., FARKas Cs. \& Marth, P., 2010. Introduction of the Hungarian Detailed Soil Hydrophysical Database (MARTHA) and its use to test external pedotransfer functions. Agrokémia és Talajtan. 59. 29-39.

National Atlas of Hungary, 1989. Akadémiai Kiadó. Budapest.

NÉMETh, T., Stefanovits, P. \& VÁRALlyay, Gy., 2005. Hungarian Soil Conservation Strategy (In Hungarian). Ministry of Environment Protection and Water Management. Budapest.

PÁlfaI, I. (Ed.), 2000. The role and significance of water in the Hungarian Plain (In Hungarian). Nagyalföldi Alapítvány. Békéscsaba.

Soil Atlas of Europe, 2005. EC DG Joint Research Centre. Office for Official Publications of the European Communities. Luxembourg.

SOMLYÓDY, L., 2000. Strategy of Hungarian water management (In Hungarian). MTA Vízgazdálkodási Tudományos Kutatócsoportja. Budapest. 
StefANOVITS, P., 1963. Soils of Hungary (in Hungarian). Akadémia Kiadó. Budapest. Stefanovits, P., 1992. Soil Science (in Hungarian). Mezőgazdasági Kiadó. Budapest. SzABOlCS, I., 1965. Salt affected soils in Hungary. Agrokémia és Talajtan. 14. Suppl. $275-290$.

Szabolcs, I., Darab, K. \& VÁRAllyay, Gy., 1969. Methods for the prognosis of salinization and alkalization due to irrigation in the Hungarian Plain. Agrokémia és Talajtan. 18. Suppl. 351-376.

SzABOLCS, I. \& VÁRALlyAY, GY., 1978. Limiting factors of soil fertility in Hungary (In Hungarian). Agrokémia és Talajtan. 27. 181-202.

SzABÓ, J., PÁSzTOR, L., SubA, Zs. \& VÁRAllyAY, GY., 1998. Integration of remote sensing and GIS techniques in land degradation mapping. Agrokémia és Talajtan. 47. 63-75.

VÁRALlyAY, GY., 1968. Salt accumulation processes in the Hungarian Danube Valley. Transaction of the $9^{\text {th }}$ Int. Congr. of Soil Sci. 1. 371-380.

VÁRAllyay, GY., 1985. Main types of water regimes and substance regimes in Hungarian soils (In Hungarian). Agrokémia és Talajtan. 34. 267-298.

VÁRALlyAY, GY., 1989. Soil degradation processes and their control in Hungary. Land Degradation and Rehabilitation. 1. 171-188.

VÁrallyay, Gy., 1994. Soil management and environmental relationships in Central and Eastern Europe. Agrokémia és Talajtan. 43. 41-66.

VÁRALlyAY, GY., 1996. Soil pollution management in Hungary. In: Remediation of Soil and Groundwater. Opportunities in Eastern Europe. (Eds.: McBEAN, E. A., BAlek, J. \& ClegG, B.) NATO ASI Series 2. Environment. Vol. 17. Part II. II/5. 87-112. Kluwer Academic Publishers. Dordrecht-Boston-London.

VÁRALlYAY, G., 1998. Multifunctional soil management for sustainable development in Hungary. Agrokémia és Talajtan. 47. 7-22.

VÁRALLYAY, GY., 2000a. Risk assessment and prevention of soil degradation processes in Hungary. In: Foresight and Precaution. (Eds.: CoтTAM et al.) 563-567. Balkema. Rotterdam.

VÁRAllyay, GY., 2000b. Scientific bases of the control of soil processes (In Hungarian). In: Székfoglalók, 1995-1998. Magyar Tudományos Akadémia. Budapest. $1-32$.

VÁRALLYAY, GY., 2003. Role of soil multifunctionality in future sustainable agricultural development. Acta Agronomica. 51. (1) 109-124.

VÁRAllyAY, GY., 2005. Soil survey and soil monitoring in Hungary. In: Soil Resources of Europe. (Eds.: JonES, R. J. A. et al.) 169-179. ESB Research Report No. 9. $\left(2^{\text {nd }}\right.$ ed.) JRC. Ispra, Italy.

VÁRALLYAY, GY., 2006. Soil degradation processes and extreme soil moisture regime as environmental problems in the Carpathian Basin. Agrokémia és Talajtan. 55. 918.

VÁRALLYAY, GY., 2010. Increasing importance of the water storage function of soils under climate change. Agrokémia és Talajtan. 59. 7-18.

VÁRAllyay, GY., 2011a. Environmental aspects of soil-water relationships in the Carpathian Basin. In: Pollution and Water Resources (Ed.: HALASI-KuN, J.) Columbia University Seminar Proceedings. Vol. XL. 2010-2011. Environmental Protection of Central Europe and USA. 237-270. 
VÁRAllyay, Gy., 2011b. Water storage capacity of Hungarian soils. Agrokémia és Talajtan. 60. Suppl. (online) (ATON) 7-26.

VÁRALLYAY, GY., 2014. Environmental aspects of soil management and moisture control. In: Proc. $6^{\text {th }}$ International Scientific and Expert Conference TEAM 2014, Kecskemét, 10-11 Nov., 2014. 26-31.

VÁRALLYAY, GY., 2015. Soil, as a multifunctional natural resource. Columella. 2. (1) 7 17.

VÁRALlyAY, Gy. \& LeSzTÁK, M., 1990. Susceptibility of soils to physical degradation in Hungary. Soil Technology. 3. 289-298.

VÁRALLYAY, GY. \& RAJKAI, K., 1989. Model for the estimation of water and solute transport from the groundwater to the overlying soil horizons. Agrokémia és Talajtan. 38. 641-656.

VÁrallyay, Gy., SzüCs, L., RajKai, K., Zilahy, P. \& Murányi, A., 1980. Hydrophysical properties of Hungarian soils and the map of their categories in the scale of 1:100 000 (In Hungarian). Agrokémia és Talajtan. 29. 77-112.

VÁRAllyay, Gy., SzÜCS, L., ZILAHY, P., RAJKAI, K. \& MURÁNYI, A., 1985. Soil factors determining the agroecological potential of Hungary. Agrokémia és Talajtan. 34. Suppl. 90-94.

VÁrallyay, Gy., Rédly, M., Murányi, A. \& SzabÓ, J., 1993. Map of the susceptibility of soils to acidification in Hungary. Agrokémia és Talajtan. 42. 35-42.

VÁRAllyay, Gy., SZABÓ, J., PÁszTOR, L. \& Michéli, E., 1994. SOTER (Soil and Terrain Digital Database) 1:500,000 and its application in Hungary. Agrokémia és Talajtan. 43. 87-108.

VÁrallyay, Gy., Szabóné Kele, G., Berényi Üveges, J., Marth, P., Karkalik, A. \& Thury, I., 2010. Soil Conditions in Hungary Based on the Data from the Soil Conservation Information and Monitoring System (SIMS). Ministry of Agriculture and Rural Development. Budapest. ISBN 978-963-06-6861-3. 